\title{
ファジィ制御系の数理的解析と産業応用の 可能性について
}

\author{
張 晌 敦*・荒 木 光 彦* \\ Mathematical Analysis of Fuzzy Control Systems \\ and on Possibility of Industrial Applications \\ Sangdon JANG* and Mituhiko ARAKI*
}

\begin{abstract}
Fuzzy control systems are analyzed from the control engineering viewpoint and possibility of their industrial applications is investigated. First, the mathematical model of a fuzzy controller which uses symmetric triangular membership functions and direct inference is derived. Then, the fuzzy control system of inverted pendulum which is often used in demonstration is analyzed, and it is shown that the pendulum falls down after a certain time. Based on the control theory, it is inferred that the pendulum will be balanced if PI element is inserted into the loop of the angle of the pendulum, and this inference is proved to be correct. The above phenomena are explained by applying linear stability theory. Lastly, possibility of industrial applications of fuzzy controllers is investigated.
\end{abstract}

Key Words: fuzzy control systems, mathematical model, inverted pendulum, stability, possibility of industrial applications

\section{1. まえがき}

昨今，さまざまな分野でファジィ制御の応用が試み られている1) 3). ファジィ制御は，操作経験や制御対 象についての知識に基づき IF-THEN 型の言語表現 で制御則が与えられる点に魅力があるが，その半面， 安定性や制御性能についての明確な保証がないため, 産業応用にあたっては「はたして大丈夫であろうか」 という不安を伴うことになる。ファジィ制御装置は制 御対象から得られたデータに基づいてファジィ推論を

†第 28 回計測自動制御学会学術講演会で発表 $(1989 \cdot 7)$

* 京都大学工学部 京都市左京区吉田本町

* Faculty of Engineering, Kyoto University, Kyoto (Received November 8, 1989)

(Revised April 27, 1990)
行い，その結果を使って操作量を定めるあのであり， 「入力されたデータに対して一意に定まる值を出力す る」という動作をしている．乙れらを制御工学という 立場からみれば非線形ゲインに他ならない。したがっ て, ファジィ制御系の挙動は, 従来の制御理論で厳密 に解析し評価するてとができるあのであり，またそう されるべきものであろう.

本論文では，乙の観点に立った解析を進め，ファジ ィ制御装置を産業応用之いう目的に使う場合, ぞのよ うな点に注意すれば十分その目的に耐えうるようにな るかを検討する．まず，応用例でよく用いられる対称 三角形メンバーシップ関数と直接推論を使うファジィ 制御装置について，その数理モデルを導く.つぎに， その結果を用いて倒立振子のファジィ制御系を解析 し，現在デモンストレーションに使われている方式で は，一定時間後振子が倒れてしまうことを示す。つぎ に，制御理論の立場から検討を加え，PI 補償によっ て振子が倒立させられるであろうととを推測し，実際 その推測が正しいととを確認する. 最後に, ファジィ 制御装置の産業応用について若干の提言を行う.

\section{2. ファジィ制御装置の数理モデル}

ファジィ制御装置には，メンバーシップ関数の選び 方および推論の仕方によって多種多様なものがありう る. ここでは, 推論過程が簡単で，ハードウェアとし て実現されているものを报う.すなわち, 入力数 2 , 出 力数 1 で, Table 1 のような九つのルールからなる ファジィ制御装置を考える，乙とに，NM，NS，ZR， PS, PM はおのおの Negative Middle, Negative Small, approximately ZeRo, Positive Small, Positive Middle の略号であり, Table 1 は $x, y$ が各条 件を満たす場合に $z$ に割当てるべき值を揭げたあので ある。 
Table 1 Rules of the fuzzy controller

\begin{tabular}{|c|c|c|c|}
\hline$y x$ & NS & ZR & PS \\
\hline NS & rule $1 \mathrm{NM}$ & rule 4 NS & rule $7 \mathrm{ZR}$ \\
\hline $\mathrm{ZR}$ & rule 2 NS & rule $5 \mathrm{ZR}$ & rule 8 PS \\
\hline PS & rule $3 \quad \mathrm{ZR}$ & rule 6 PS & rule $9 \mathrm{PM}$ \\
\hline
\end{tabular}

ちなみに, ルール 4 は IF $x$ is ZR and $y$ is NS THEN $z$ is NS というルールである. とのようなル ールの集合は原点へ制御量を保持する目的に使用でき る. $x \in \mathrm{NS}(, \mathrm{ZR}, \mathrm{PS}), y \in \mathrm{NS}(, \mathrm{ZR}, \mathrm{PS}), z \in \mathrm{NM}(, \mathrm{NS}$, $\mathrm{ZR}, \mathrm{PS}, \mathrm{PM})$ に対応するメンバーシップ関数の形は

Fig. 1 (a)，（b），（c）の通りとする.メンバーシ ップ関数についてもルールごとに番号を付け, $f_{x i}(x)$, $f_{y_{i}}(y), f_{z i}(z)(i=1, \cdots, 9)$ という記号で表わす. メン バーシップ関数の形を決定する $a, b, c$ が制御装置 の可調整パラメータとなる.

入力から出力 (操作量) を求める方法としては Mamdani の直接推論を使うものとする.すなわち, ルール $i$ に対する入力 $\left(x_{o}, y_{o}\right)$ の適合度 $\alpha_{i}$ を

$$
\alpha_{i}=\min \left[f_{x_{i}}\left(x_{0}\right), f_{y_{i}}\left(y_{0}\right)\right] \quad i=1, \cdots, 9
$$

で定義する. $\alpha_{i}(i=1, \cdots, 9)$ を使ってルールどとに出 力 $z$ のンバーシップ関数をつぎのように修正する.

$$
M_{i}(z)=\min \left[\alpha_{i}, f_{z i}(z)\right] \quad i=1, \cdots, 9
$$

このルール別修正メンバーシップ関数 $M_{i}$ から総合修 正メンバーシップ関数 $M_{0}$ 。次式で定める.

$$
M_{0}(z)=\max \left\{M_{1}(z), \cdots, M_{9}(z)\right\}
$$

最後に総合修正メンバーシップ関数 $M_{0}$ の重心

$$
z_{o}=\int z \cdot M_{o}(z) d z / \int M_{o}(z) d z
$$

を求め, 乙れを入力 $\left(x_{0}, y_{0}\right)$ に対する出力とする.

以上から $z_{0}$ は $x_{0}, y_{0}$ の 2 変数関数

$$
z_{o}=F\left(x_{0}, y_{o}\right)
$$

になることがわかる. 関数 $F$ の形を具体的に求めるた めには入力空間，すなわち $x-y$ 平面を Fig. 2 に示 した 16 個の領域に分けて考えるとよい，各領域での 計算は，ほとんど同じになるので, 代表例として領域 $D_{1}(0 \leqq x \leqq a ; 0 \leqq y \leqq b)$ での計算過程を示しておく.

\begin{tabular}{r|r|r|l}
$D_{9}$ & $D_{8}$ & $D_{7}$ & $D_{6}$ \\
\hline$D_{10}$ & $D_{2}$ & $D_{1}$ & \multicolumn{1}{|c}{$D_{5}$} \\
\hline$-a$ & 0 & $a$ & \\
$D_{11}$ & $D_{3}$ & $D_{4}$ & $D_{16}$ \\
\hline$D_{12}$ & $D_{13}$ & $D_{14}$ & $D_{15}$
\end{tabular}

Fig. 2 Division of the input space

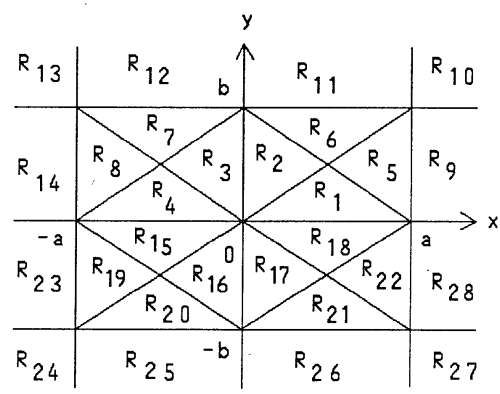

Fig. 3 Subdivision of $D_{i}$ 's

(1)入力の各成分に対するメンバーシップ関数の值 領域 $D_{1}$ ではルール 5，6，8，9 が当てはまり， 各ルールについてのメンバーシップ関数 $f_{x i}\left(x_{0}\right)$, $f_{y_{i}}\left(y_{o}\right)$ の值はつぎのようになる.

$$
\begin{aligned}
& f_{x 5}\left(x_{o}\right)=f_{x 6}\left(x_{o}\right)=-x_{o} / a+1 \\
& f_{x 8}\left(x_{o}\right)=f_{x 9}\left(x_{o}\right)=x_{o} / a \\
& f_{y 5}\left(y_{o}\right)=f_{y 8}\left(y_{o}\right)=-y_{o} / b+1 \\
& f_{y 6}\left(y_{o}\right)=f_{y 9}\left(y_{o}\right)=y_{o} / b
\end{aligned}
$$

(2)適合度 $\alpha_{i}$

適合度 $\alpha_{i}$ は $f_{x i}$ と $f_{y_{i}}$ との最小値として定まる から， $f_{x i}$ と $f_{y_{i}}$ の值の大小関係にしたがって領域 $D_{1}$ をさらに四つの小領域に分解する (Fig. 3 参照). 分け方から，各小領域に怙ける適合度の值は自明であ ろうが, ちなみに $R_{1}$ における適合度は

$$
\begin{array}{ll}
\alpha_{5}=-x_{o} / a+1, & \alpha_{6}=y_{0} / b \\
\alpha_{8}=x_{0} / a, & \alpha_{9}=y_{o} / b
\end{array}
$$

である．以上では四つのルールに対

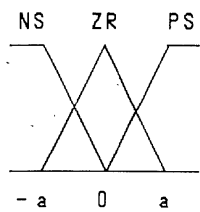

(a) $f_{x}$

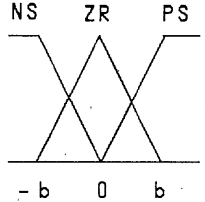

(b) $f_{y}$

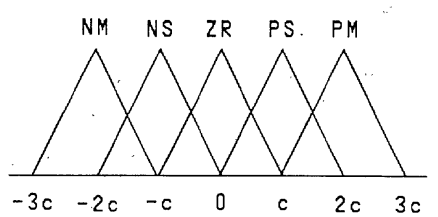

(c) $f_{z}$ する適合度だけ求めたが，他のルー ルについての適合度はもちろん0で ある。

(3)ルール別の修正メンバーシップ 関数 $M_{i}$

たとえば，小領域 $R_{1}$ での修正メ ンバーシップ関数 $M_{i}(z)$ は Fig. 4

Fig. 1 Membership functions 

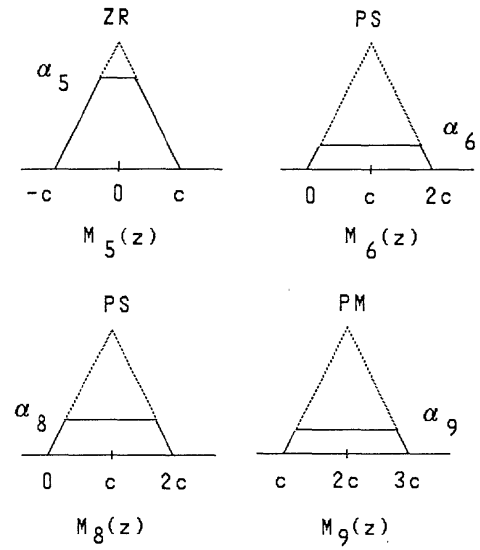

(a) Modified membership function $M_{i}(z)$

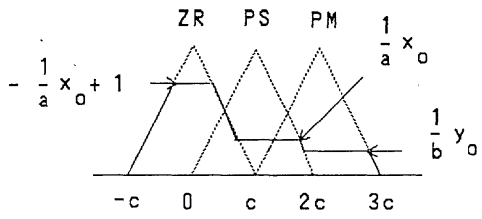

(b) Total modified membership function $M_{0}(z)$

Fig. 4 Example of $M_{i}(z)$ and $M_{o}(z)$

(a)のとおりになる.

(4)総合修正メンバーシップ関数 $M(z)$

以上より，小領域 $R_{1}$ での総合修正メンバーシップ 関数. $M_{0}(z)$ は Fig. 4(b) のとおりになる.

(5)出力 $z_{0}$

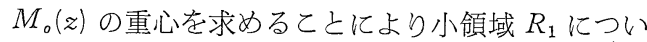
ては

$$
z_{0}=c z^{\prime}, \quad z^{\prime}=\frac{-y^{\prime 2}+5 y^{\prime}-x^{\prime 2}+3 x^{\prime}}{-2\left(x^{\prime 2}-y^{\prime}-x^{\prime}-1\right)}
$$

となる，ただし， $x^{\prime}=x_{o} / a, y^{\prime}=y_{o} / b$ とする．

以上の計算を, 入力空間のすべての領域について実 行すれば $z_{0}$ を与える関数 $F$ の全貌が明らかとなる. $y \geqq 0$ の部分についての計算結果を Table 2 に示して おく.ただし， $R_{1} \sim R_{14}$ は Fig. 3 の小領域である. Table 1 のファジィ推論のルールは原点対称だから関 数 $F(x, y)$ も原点対称になる. したがって, $y \leqq 0 の$ 部分の $F(x, y)$ は Table 2 の式の $x^{\prime}, y^{\prime}$ を $-x^{\prime}$,

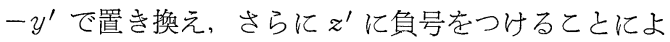
って求められる.

$F(x, y)$ の性質を調べておこう。原点における $F(x, y)$ の偏微分係数を領域別に求めてみると

$$
\begin{aligned}
& \frac{\partial F}{\partial x}=\frac{3 c}{2 a}, \frac{\partial F}{\partial y}=\frac{3 c}{2 b}\left(x, y \in R_{3}, R_{4}, R_{17}, R_{18}\right) \\
& \frac{\partial F}{\partial x}=\frac{3 c}{2 a}, \frac{\partial F}{\partial y}=\frac{5 c}{2 b}\left(x, y \in R_{1}, R_{15}\right)
\end{aligned}
$$

\begin{tabular}{|c|c|}
\hline Region & $\begin{array}{l}\text { Function } F\left(x^{\prime}, y^{\prime}\right) / c \\
x^{\prime}=x / a, \quad y^{\prime}=y / b\end{array}$ \\
\hline$R_{1}$ & $\frac{-x^{\prime 2}+3 x^{\prime}-y^{\prime 2}+5 y^{\prime}}{2\left(-x^{\prime 2}+x^{\prime}+y^{\prime}+1\right)}$ \\
\hline$R_{2}$ & $\frac{-x^{\prime 2}+5 x^{\prime}-y^{\prime 2}+3 y^{\prime}}{2\left(-y^{\prime 2}+y^{\prime}+x^{\prime}+1\right)}$ \\
\hline$R_{3}$ & $\frac{x^{\prime 2}+3 x^{\prime}-y^{\prime 2}+3 y^{\prime}}{2\left(-y^{\prime 2}+y^{\prime}-x^{\prime}+1\right)}$ \\
\hline$R_{4}$ & $\frac{x^{\prime 2}+3 x^{\prime}-y^{\prime 2}+3 y^{\prime}}{2\left(-x^{\prime 2}-x^{\prime}+y^{\prime}+1\right)}$ \\
\hline$R_{5}$ & $\frac{x^{\prime 2}-x^{\prime}-3 y^{\prime 2}+5 y^{\prime}+2}{2\left(-y^{\prime 2}+y^{\prime}-x^{\prime}+2\right)}$ \\
\hline$R_{6}$ & $\frac{-3 x^{\prime 2}+5 x^{\prime}+y^{\prime 2}-y^{\prime}+2}{2\left(-x^{\prime 2}+x^{\prime}-y^{\prime}+2\right)}$ \\
\hline$R_{7}$ & $\frac{-x^{\prime 2}+x^{\prime}+y^{\prime 2}+y^{\prime}}{2\left(-x^{\prime 2}-x^{\prime}-y^{\prime}+2\right)}$ \\
\hline$R_{8}$ & $\frac{-x^{\prime 2}+x^{\prime}+y^{\prime 2}+y^{\prime}}{2\left(-y^{\prime 2}+y^{\prime}+x^{\prime}+2\right)}$ \\
\hline$R_{9}$ & $\frac{-3 y^{\prime 2}+5 y^{\prime}+2}{2\left(-y^{\prime 2}+y^{\prime}+1\right)}$ \\
\hline$R_{10}$ & 2 \\
\hline$R_{11}$ & $\frac{-3 x^{\prime 2}+5 x^{\prime}+2}{2\left(-x^{\prime 2}+x^{\prime}+1\right)}$ \\
\hline$R_{12}$ & $\frac{-x^{\prime 2}+x^{\prime}+2}{2\left(-x^{\prime 2}-x^{\prime}+1\right)}$ \\
\hline$R_{13}$ & 0 \\
\hline$R_{14}$ & $\frac{y^{\prime 2}+y^{\prime}-2}{2\left(-y^{\prime 2}+y^{\prime}+1\right)}$ \\
\hline
\end{tabular}

Table 2 Nonlinear function which characterizes the fuzzy controller

$$
\frac{\partial F}{\partial x}=\frac{5 c}{2 a}, \frac{\partial F}{\partial y}=\frac{3 c}{2 b}\left(x, y \in R_{2}, R_{16}\right)
$$

となる，すなわち， $F(x, y)$ は方向によって傾きが異 なる（すなわち，全微分不可能な）関数であって，原 点に本質的な非線形性を有することがわかる.

\section{3. 直線軌道を走行する台車上での 倒立振子のファジィ制御}

ファジィ制御装置を使った倒立振子の制御はファジ イ制御の有効性を示すためのデモンストレーションと してよく使われてきた。文献 4)，5）をみれば，実際の 制御系が Fig.5 のようになっているととがわかる. 制御の目的は走行状態，静止状態を間わず振子を倒立 させればよいものとされている，この装置では数 $\mathrm{m}$ の距離しか走行できない（したがって，そこで実験を 終える) わけだが，以下では十分長い距離走行できる 


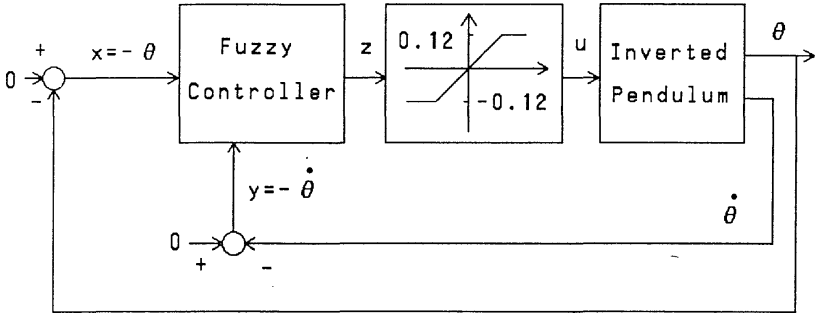

(a) Structure of the contol system

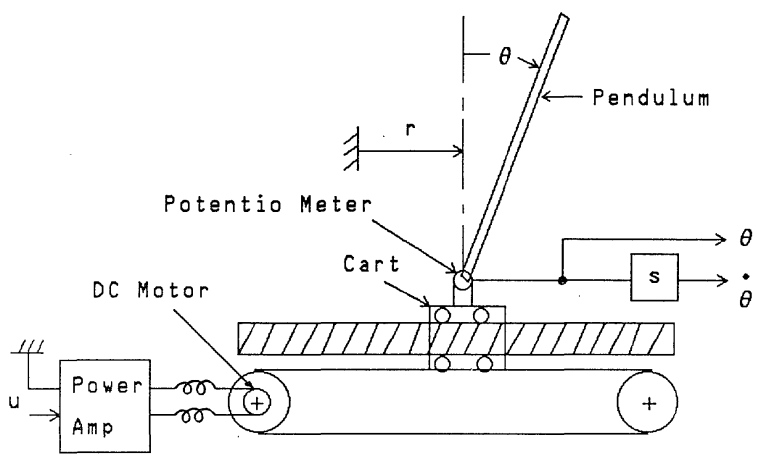

(b) Inverted pendulum on the linear truck

Fig. 5 Fuzzy control of the inverted pendulum

ものとして検討を行う。乙れは，本論文が「プロセス 制御などの目的でファジィ制御装置を使用した場合に あ,はたしてデモンストレーションのようにうまく行 くか」という疑問に答えるととを主目的としているか らである。

Fig. 5 (b) の倒立振子系の運動方程式は ${ }^{6)}$

$$
(M+m) \ddot{r}+m l \cos \theta \ddot{\theta}=-D \dot{r}+m l \dot{\theta}^{2} \sin \theta-G u
$$

$m l \cos \theta \ddot{r}+\left(\sigma+m l^{2}\right) \ddot{\theta}=-C \dot{\theta}+m l g \sin \theta$

である. $u$ は電力増幅器への入力電圧, $G$ は駆動系の 利得係数, $r$ は台車の位置, $\theta$ は振子の倒れ角（垂直 上方を $0 ） M, D$ は台車の質量および粘性摩擦係数, $m, 2 l, C$ は振子の質量, 長さおよび粘性摩擦係数, б振子は慣性モーメントに関するパラメータである. 以下のシミュレーションでは，古田氏の教科書にある パラメータ值と飽和条件を用いる ${ }^{6)}$. すなわち

$M=0.392 \mathrm{~kg}, \quad m=0.074 \mathrm{~kg}, \quad D=2.847 \mathrm{~kg} / \mathrm{s}$,

$G=56.29 \mathrm{~N} / \mathrm{V}, \quad g=9.8 \mathrm{~m} / \mathrm{s}^{2}, \quad l=0.358 \mathrm{~m}$, $\sigma=0.0095 \mathrm{kgm}^{2}, \quad C=0.00218 \mathrm{kgm}^{2} / \mathrm{s}$

とし，アンプの飽和から生ずる制約

$$
|u| \leqq 0.12 \mathrm{~V}
$$

を課す.ファジィ制御装置としては前節の装置を用 い，振子の倒れ角と倒れ角速度をそれぞれ入力 $x, y$ として, 出力 $z$ を(8) 式の飽和要素に通したものを電
力増幅器への電圧 $u$ とする.

前章の数理モデルを使って上のファジィ 制御系のシミュレーションを行った結果を

Fig. 6 に示す.ただし，この結果は，ファ ジィ制御装置のパラメータを $a=0.2 \mathrm{rad}, b=0.5 \mathrm{rad} / \mathrm{s}, c=1.0 \mathrm{~V}$ 初期条件を

$$
\theta(0)=0.01 \mathrm{rad}, \text { ほ }
$$

と選んだときのものである. Fig. 6 から， この場合には, 台車が約 $38 \mathrm{~m}$ 走ったとき振 子が倒れてしまうことがわかる。パラメータ $a, b, c$ をこれ以外のいろいろな值に設定 しても，走行距離は異なるが，最後には振子 が倒れてしまうという結果は同じであった。

振子が倒れる理由として，直観的にはつぎ の説明が可能である。ファジィ制御装置は 非線形ゲインであり，入力電圧 $u$ から倒れ角 $\theta$ への伝達特性は定位性であるから，定常的 な外乱があれば倒れ角に定常偏差が生じる.

Fig. 6(c) をみれば確かに $\theta$ に定常偏差が (短期的にみて) 生じているようにみえる. この定常偏差を維持するためには台車を常に 加速するととが必要であり，乙の事実は Fig. 6(d) で台車の速度が徐々に増加しているととから裹付けら れる．ところが，アンプの出力に上限があるために， ある時点で加速ができなくなり振子は倒れてしまう. このととは， $\theta$ の波形とuの波形を比較すれば確認で きる。

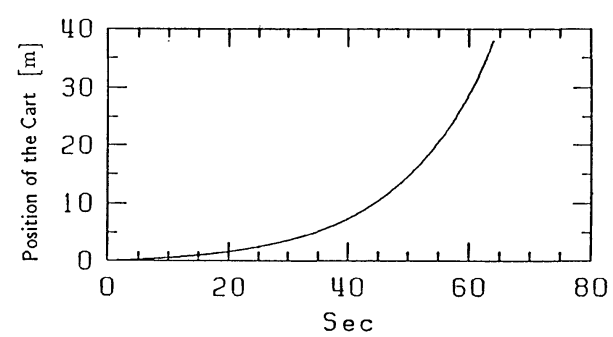

(a) Position of the cart

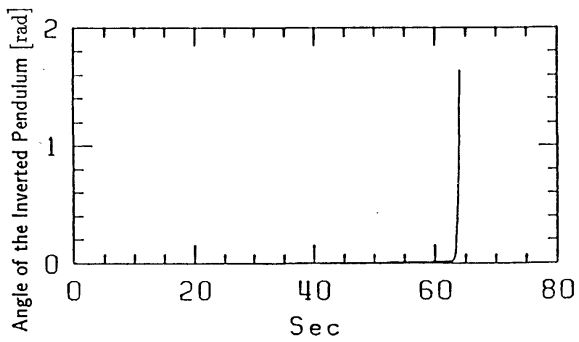

(b) Angle of the pendulum 


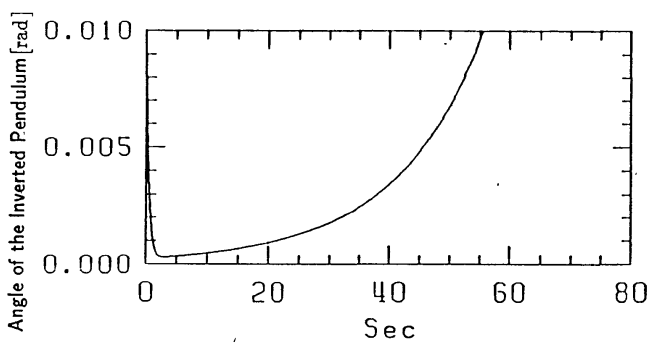

(c) Enlargement of (b)

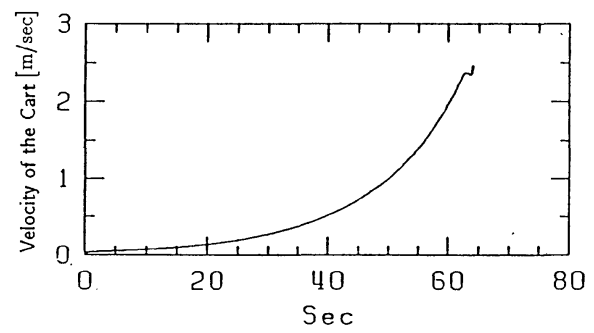

(d) Velocity of the cart

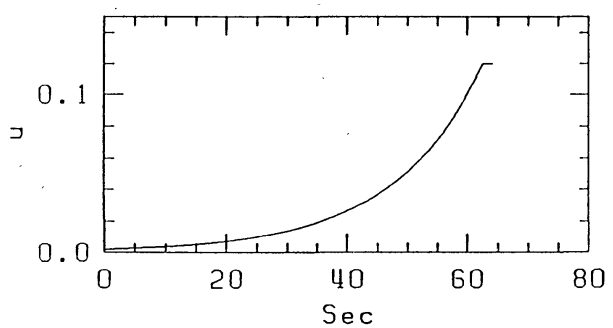

(e) Control input $u$

Fig. 6 Simulation results of the system of Fig. 5

上のように，振子が倒れる主な理由が定常偏差の存 在にあるとすれば，I 要素または PI 要素で定常偏差 を除去することによって，振子を安定に倒立させられ るのではないかと考えられる. そこで， Fig. 7 のよ うに倒れ角 $\theta$ のループにPI 補償要素を入れてみると,

Fig. 8 のように倒立状態が保持できるととがわかっ た. ただし，PI 補償要素のパラメータは $K=5, T=$ 2.5 とした.

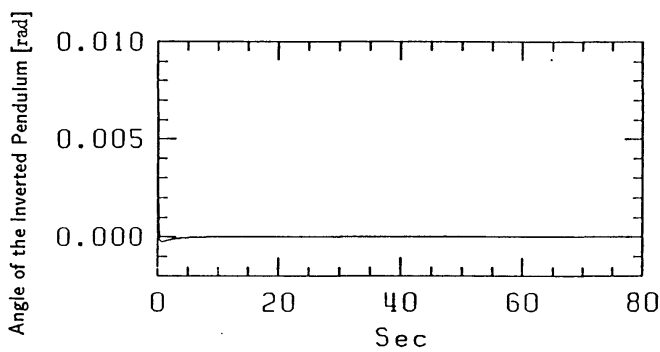

Fig. 8 Simulation results of the system of Fig. 7

\section{4. 線形理論による解析}

前章で, 従来型のファジィ制御系で振子が倒れる理 由が，振子の倒れ角に生じる定常偏差であるととを示 唆した，しかし，乙の説明はつぎの点で不十分なとこ ろを残している．すなわち，乙の説明は定常外乱を前 提としているが（目標值が０であるととに注意），そ のような外乱は explicit には加わっていない。毛 ろん，よく考えてみると，台車の位置を制御せずに自 由にしていることが結果的に定常外乱として作用して いるすのと解釈できそうであり，定常偏差が生じる原 因を見出すことはできる，ただし，台車の動きも振子 と一体となった微分方程式で記述されるわけだから， 上のような解釈を導入するととは，動的システム理論 という立場から不満足なものといわざるをえない．乙 の点を償うため, 当章では, 線形理論による安定解析 を行う。ただし，2章で述べたように，ファジィ制御 装置は原点で全微分不可能だから，微少変動に対する 近似としての線形化はできない，したがって，㛜密に いえば当章の解析は単なる比較の対象としての意味し かもちえないが次章の検討結果（ファジィ制御装置の 傾きの下限を線形ゲインと合せたときの結果）と総合 すれば，乙れによってシステムの特性が十分解明され たとみなしてよかろう。

倒立振子の状態党 $v=\left[\begin{array}{llll}r & \theta & \dot{r} & \dot{\theta}\end{array}\right]^{T}$ とおいて, 原点 の周りで線形化すれば次式が得られる.

$$
\dot{v}=A v+b u
$$

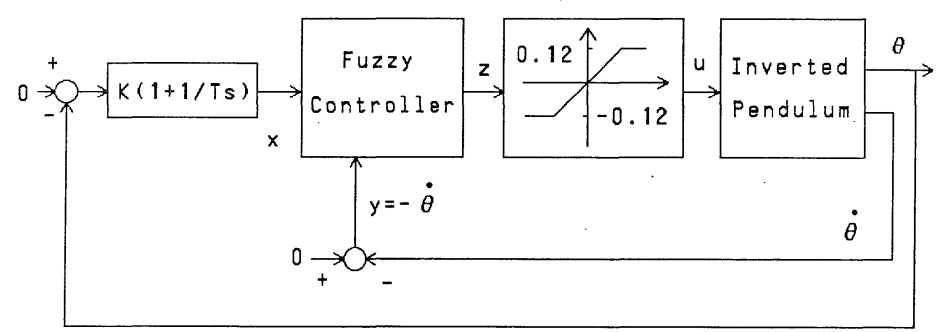

Fig. 7 Structure of the control system with PI

$$
\begin{aligned}
& A=\left[\begin{array}{cccc}
0 & 0 & 1 & 0 \\
0 & 0 & 0 & 1 \\
0 & a_{32} & a_{33} & a_{34} \\
0 & a_{42} & a_{43} & a_{44}
\end{array}\right], \\
& b=\left[\begin{array}{l}
0 \\
0 \\
b_{3} \\
b_{4}
\end{array}\right] \\
& a_{32}=-m^{2} l^{2} g / \beta, \\
& a_{33}=-D\left(\sigma+m l^{2}\right) / \beta,
\end{aligned}
$$


$a_{34}=C m l / \beta, a_{42}=(M+m) m l g / \beta, \quad a_{43}=D m l / \beta$,

$a_{44}=-(M+m) C / \beta, \quad b_{3}=-\left(\sigma+m l^{2}\right) G / \beta$,

$b_{4}=m l G / \beta, \quad \beta=\sigma(M+m)+M m l^{2}$

ファジィ制御装置の代わりに線形ゲィン

$$
H=\left[\begin{array}{llll}
0 & h_{1} & 0 & h_{2}
\end{array}\right]
$$

でフィードバックを行うあのとすると, 閉ループ系の 特性方程式は

$$
s\left[s^{3}+\left(Q_{11}+Q_{12} h_{2}\right) s^{2}+\left(Q_{21}+Q_{22} h_{1}\right) s+Q_{31}\right]=0
$$

$$
\begin{aligned}
& Q_{11}=-a_{33}-a_{44}, \quad Q_{12}=b_{4}, \\
& Q_{21}=a_{33} a_{44}-a_{42}-a_{34} a_{43}, \quad Q_{22}=b_{4}, \\
& Q_{31}=-a_{43} a_{32}+a_{33} a_{42}
\end{aligned}
$$

となる. したがって，閉ループ極は $s=0$ および(11) 式の [ ] 内を 0 とするような三つの極からなる. 方 程式を調べてみれば， $s=0$ は，台車の位置に対応す る不可制御な極であることがわかる：［］内の定数 項が

$$
Q_{31}=\frac{D m^{3} l^{3} g-D\left(\sigma+m l^{2}\right)(M+m) m l g}{\beta^{2}}<0
$$

となるから，残りの三つの極のなか，少なくとも一つ は不安定である（ラウスの条件より）．いい換えれ ば，(10)式の線形フィードバックでは振子を安定に倒 立させることはできない，乙のことから，とのシステ ムが不安定になる原因が, 台車の粘性摩擦係数の存在 $(D \neq 0)$ にあることがわかる.

今度は, Fig. 7 のように, 振子の倒れ角のループ に PI 補償要素を入れたときを考える.ただし，先と 同様ファジィ制御装置は(10)式の線形フィードバック で置き撸える. 閉ループ系の特性方程式は

$$
\begin{aligned}
& s^{2}\left[s^{3}+\left(Q_{11}+Q_{12} h_{2}\right) s^{2}+\left(Q_{21}+K b_{4} h_{1}\right) s\right. \\
& \left.\quad+Q_{31}+K b_{4} h_{1} / T\right]=0
\end{aligned}
$$

で，閉ループ系は原点に二つ極をむつ．係数行列を調 べれば，乙の二つの極は，台車の位置および PI 調節 計の積分器におのおの対応する不可制御な極で, 二 つとあサイズ 1 のジョルダンブロックに対応するあの であることがわかる．ラウスの判別法を使って，残り の三つの極の安定性を調べると， $h_{1}, h_{2}$ が Fig. 9 の

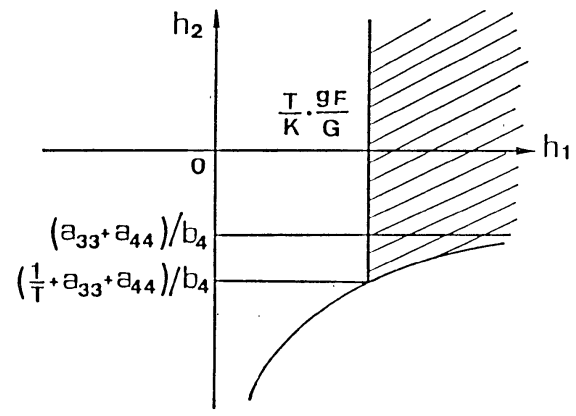

Fig. 9 Stability region of the linearlized system 斜線部分にあれば安定であるととがわかる，したがっ て，乙の場合には振子を安定に倒立させることができ る.ただし，不可制御な極が原点に二つあるため，台 車の位置および積分器の值は初期条件で一意に定めら れてしまう。

\section{5. 検 討}

\section{1 従来型のファジィ制御方式による倒立振子系 の検討}

ファジィ制御装置の原点での傾き(6)について記号

$$
\underline{h}_{1} \triangleq \frac{3}{2} \frac{c}{a}, \quad \bar{h}_{1} \triangleq \frac{5}{2} \frac{c}{a}, \underline{h}_{2} \triangleq \frac{3}{2} \frac{c}{b}, \quad \bar{h}_{2} \triangleq \frac{5}{2} \frac{c}{b}
$$

を導入しておく．前章の解析から，ファジィ制御装置 を線形ゲインに置き換えたとき，閉ループ系が 1 個の 不安定極（ $s=0$ は除く）をむつことがわかっており, 振子が倒れるまでの時間はこの不安定極の大きさによ って決められると推測される. そこでまず，線形制御 系で， $h_{2}$ を固定して $h_{1}$ を変化させたときの不安定極 の值を求めた (Table 3 第 1 欄). つぎに, ファジィ 制御装置の $y$ についての傾きの下限 $\underline{h}_{2}$ を $h_{2}$ に一致 させ， $x$ についての傾きの下限 $\underline{h}_{1}$ を $h_{1}$ に一致させ て（この対応関係については次項参照）シミュレーシ ヨンを行い, 振子が倒れるまでの時間, 距離を求めた (Table 3 第 2 , 第 3 欄). 乙れから, 最初に述べた推 測が正しくて，なるべく長時間倒立させておくために

Table 3 Unstable poles of the linearized system and running time and distance of the fuzzy control system $\left(f_{2}=3\right)$

\begin{tabular}{c|c||c|c}
\hline \hline$h_{1}$ & $\begin{array}{c}\text { The value of the unstable pole } \\
\text { of the linearized system }\end{array}$ & \multicolumn{2}{|c|}{ Response of the fuzzy control system } \\
\cline { 2 - 3 } & $4.7348 \times 10^{-1}$ & Running time $(\mathrm{s})$ & Running distance $(\mathrm{m})$ \\
\hline 7.5 & $6.2772 \times 10^{-2}$ & 11.5 & 10 \\
\hline 75 & $6.5723 \times 10^{-3}$ & 68 & 38 \\
\hline
\end{tabular}


は $a$ を小さく，cを大きく選べばよいことがわかる.

\subsection{PI 補償要素付ファジィ制御方式による 倒立振子系の検討}

PI 補償要素を導入したファジィ制御系について, パラメータ空間での安定領域を線形化した系の安定領 域と比較してみる. ファジィ制御装置の $y$ 亿関する傾 きの下限 $\underline{h}_{2}$ を正の值に選んで, $x$ 亿関する傾きの下 限 $\underline{h}_{1}$ を変化させてシミュレーションしてみると， $\underline{h}_{1}$ についての安定限界之線形系の場合の安定限界がほぼ （約 1/50ぐらいの精度で）一致するととがわかった. すなわち，乙の場合の安定性は，傾きの下限を使った 線形モデルでほぼ正確に解析できる，乙の制御系の安 定領域は，Fig. 9 のように， $h_{1}, h_{2}$ が大きい側にひ ろがっているから，傾きの下限で安定性が定まるとい うのは妥当な結果といえる.

\section{3 円軌道上を走行する台車の上での倒立振子の ファジィ制御}

今まで，Fig. 5(b) のような装置を扱ってきたが， 倒れるまでの走行距離が $10 \mathrm{~m}$ 以上になるので解析結 果を実験的に確認することが難しい，そこで Fig. 10 のように，円軌道上を走行する台車の上で振子を倒立 させるシステムについて速度制御型のドライバを用 いた場合あ検討してみた．その結果は本質的に直線軌 道上の倒立振子の場合と同様であった．また，ての場 合については，実験的にも，長時間後に振子が倒れる てとが他の研究者によって確認されているが，シミュ レーション結果との定量的比較は行っていない.

\section{4 振子を倒立させる方法について}

振子を倒立させる方法として, Fig. 7 以外にどん な可能性があるか考察しておく，3章および 4 章で明 らかにしたように，振子が倒れる主な原因は，制御装 置が出力のゲインフィードバックであるとと，および 粘性摩擦の存在の二つである. 後者は実在の系では避

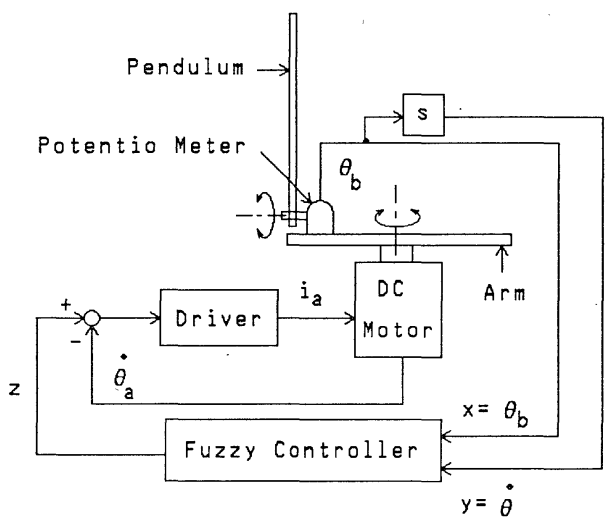

Fig. 10 Inverted pendulum on the circular truck
けられないから，前者を変更する必要がある．メン バーシップ関数の形を変えたりファジィ推論を min$\max$ 以外の方法で行ったとしてあゲインフィードバ ックであるととに変わりはないから，振子を倒立させ るととはできない，倒立させるためには，ファジィ制 御装置に何らかの積分性をもたせるか，もしくはオブ ザーバを使って状態変数を推定するという方法が考え られる．積分性をむたせて安定化する方法は Fig. 7 以外に何通りあ考えられる（単純にI 要素をいれる， dynamical fuzzy 装置を作る，など）が，その本質は 4 章の終りに述べたことに尽きる，オブザーバを使う 場合はファジィ推論を現代制御理論の枠組みで用いる ととになる。

\section{5 他の文献との比較}

ファジィ装置を使った倒立振子制御系の解析とし て，文献 9)〜11) の報告がある. 文献 9)では，当論文 と同様のファジィ制御装置を使うものとし, シミュレ ーションおよびリアプノフの方法による安定解析を行 いルールをうまく選べばシズテムを安定化できると述 べている，ただし，ての文献では; 粘性摩擦をすべて 無視した方程式を基に検討している. 文献 10)はシミ ニレーションを行ったあので，時間が 5 秒，台車の走 行距離が約 $1.6 \mathrm{~m}$ までの結果を示している. この文献 では，システムの方程式として摩擦を含むすのと含ま ないあのの両方が掲げられていて，シミュレーション でどちらかを使ったか示されていない，文献11)はや はり台車とレールとの粘性摩擦係数を無視した系に 対してシミュレーションと安定解析を行ったもので ある. 3 章で述べたように，系が不安定になる原因の 一つは台車の粘性摩擦係数の存在であり, また振子が 倒れるまで（当論文のパラメータ值のとき）時間で 20 秒以上，距離で $10 \mathrm{~m}$ 以上かかっている. てのことか ら, 上記三つの文献の結果は, 実際のシステムに生じ る長時間の現象を説明するには不十分であると考えら れる.

\section{6. ファジィ制御装置の産業応用の 可能性について}

本論文では，ファジィ制御系の一例についての検討 を行っただけであるから，その結果に基づいてファジ ィ制御装置の産業応用について一般的結論を下すのは 早計であろう.しかし, 当論文によって得られた知見 から若干の提言は可能と考えられるので，それについ て述べる。まず，本論文の結果は，簡単な実験と直観 的判断だけに頼って安易にファジィ制御を導入するて とが危険であることを示唆している，また，PI 動作 
の導入によって安定な系が作れたという事実は，ファ ジィ制御装置を使う場合においても，オーソドックス な制御理論が有効であることを示している. 一方, 他 の文献では，ファジィ制御が実用目的に使われている ことが報告されている(1) そ) それらの応用を詳しくみ

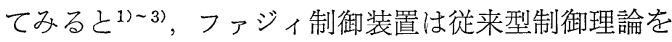
否定する形ではなく，むしろ協調する形で使われてい る. これらの事実を総合すれば，ファジィ方式とオー ソドックスな制御理論とは，お互いの長所を生かした 形で用いられるのが適当と考えられる. その場合に は，

（a）ファジィ制御を安心して適用してよい範囲 （制御対象のクラスや動作の及ぶ範囲）を明 らかにすること

が第一の研究課題となろう。この目的には，絶対安定 問題に 関する研究結果 ${ }^{8}$ を改良して使うのが有効であ ろう。つぎに，すう少し細かく，ファジィ方式と制御 理論の分担範囲を本論文の結果を参考に考えてみると

（b）ダイナミクスに関する基本的構造（微分積分 要素の使い方, オブザーバなど）は制御理論 で決め，従来の制御理論では扱い難いような 面での付加価值をファジィ方式によって与え る

のが一つのあり方といえよう.ファジィ方式によって 与えられる付加価值として，筆者らは

（c）経営者, 運転員といった一般の人々に対し て，制御系の調整作業を open にするための ヒューマンインタフェースとしての機能

(d) 学習, 多目的最適化, スケジュール調整とい ったフィードバックループの上位に位置する 機能

を高く評価するものである，なお，ファジィ制御の他
の特徽として「乗り心地, 使い心地といった漠然とし た評価基準を改善するのに線形制御より有効である」 という指摘がある. 本論文で示したように, ファジィ 制御装置は本質的非線形性を含んでいるから，線形制 御でできないととができるという可能性は否定できな い. ただし，現時点では，上のような評価基準を改善 していくための体系的設計理論がないので，その能力 を生かすためにはかなりの手数が必要となることを覚 悟すべきである.

\section{参 考 文 献}

1）柳下，伊藤，菅野：ファジィ理論の浄水場薬品注入制御 への応用，システムと制御，28-10，597/604 (1984)

2) 前田，村上：Fuzzy Logic コントローラによる自動車 の速度制御, 計测自動制御学会論文集, 21-9, 984/989 (1985)

3）安信，宮本，井原：Fuzzy 制御による列車定位置停止制 御, 計測自動制御学会論文集, 19-11，873/880 (1983)

4) 村上周太：ファジィ制御，コンピュートロール，22，51/ 58 (1988)

5) 山川 烈：Fuzzy コンピュータの発想, 講談社 (1988)

6) 古田, 美多, 川路, 原：メカニカルシステム制御, オー 么社 (1984)

7) 北村新三：ファジィルール制御系の安定解析のための 円板形条件, 第 33 回システム制御情報学会研究発表講演 会, No. 5039 (1989)

8) V. A. Yakubovich: Frequency Conditions for the Absolute Stability of Control Systems with Several Nonlinear or Linear Nonstationary Blocks, Automation and Remote Control, 28-6, 857/880 (1967)

9) Y. Y. Chen: Stability Analysis of Fuzzy Control -A Lyapunov Approach, ICSMC '87, 3, 1027/1031 (1987)

10) 川路, 野口：ファジィ推論による倒立振子の安定化制御, 第 5 回ファジィシステムシンポジウム講演論文集, 107/ 113 (1989)

11) 川路, 汐月, 野口：倒立振子のファジィ制御之安定性解 析, 第 18 回制御理論シンポジウム資料, 315/320 (1989) 